\title{
Secretory Leukocyte Protease Inhibitor in Preterm Labor and Pregnancy
}

\author{
Secretory Leukocyte Protease Inhibitor pada Persalinan dan Kehamilan Prematur
}

\author{
Ferriyanto Sutiono, Juneke J Kaeng, Maria FT Loho \\ Department of Obstetrics and Gynecology \\ Faculty of Medicine Universitas Sam Ratulangi/ \\ Prof. Dr. R. D. Kandou Central General Hospital \\ Manado
}

\begin{abstract}
Objective: To investigate the levels of secretory leukocyte protease inhibitor (SLPI) in women with preterm labor and pregnancy.

Methods: SLPI level examination conducted to 32 samples of pregnant women who meet the inclusion and exclusion criteria, consists of 16 preterm labor and 16 preterm pregnancy. Sample analysis carried out in Prodia Laboratory Jakarta. SLPI level examination used ELISA method. The obtained data processed by SPSS software version 20.0 and discussed with existing literature theory.

Results: Mean plasma SLPI level in patients with preterm labor is $30.319 \mathrm{ng} / \mathrm{ml}$ and median: $29.950 \mathrm{ng} / \mathrm{ml}$ with p value: 0.652 while the mean on preterm pregnancy is $45.975 \mathrm{ng} / \mathrm{ml}$ and median: $41.600 \mathrm{ng} / \mathrm{ml}$ with p value: 0.005 .

Conclusion: There are significant differences of SLPI level between preterm labor and preterm pregnancy.

[Indones J Obstet Gynecol 2018; 6-3: 137-142]

Keywords: preterm labor, preterm pregnancy, SLPI
\end{abstract}

\begin{abstract}
Abstrak
Tujuan: Untuk mengetahui kadar secretory leukocyte protease inhibitor (SLPI) pada persalinan dan kehamilan prematur.

Metode: Dilakukan pemeriksaan kadar SLPI pada 32 sampel ibu hamil yang memenuhi kriteria inklusi dan eksklusi, terdiri dari 16 persalinan prematur dan 16 kehamilan prematur. Analisis sampel dilakukan di Laboratorium Prodia Jakarta. Pemeriksaan kadar SLPI menggunakan metode ELISA. Data yang diperoleh diolah dengan menggunakan perangkat lunak SPSS versi 20.0 dan dilakukan pembahasan menggunakan teori kepustakaan yang ada.
\end{abstract}

Hasil: Rerata kadar SLPI plasma pada pasien persalinan prematur yaitu $30.319 \mathrm{ng} / \mathrm{ml}$ dan median : $29.950 \mathrm{ng} / \mathrm{ml}$ dengan $p$ value: 0.652 , sedangkan rerata pada kehamilan prematur yaitu : $45.975 \mathrm{ng} / \mathrm{ml}$ dan median : $41.600 \mathrm{ng} / \mathrm{ml}$ dengan $\mathrm{p}$ value: 0,005 .

Kesimpulan: Terdapat perbedaan kadar SLPI yang signifikan antara persalinan prematur dengan kehamilan prematur.

[Maj Obstet Ginekol Indones 2018; 6-3: 137-142]

Kata kunci: kehamilan prematur, persalinan prematur, SLPI

Correspondence: Ferriyanto Sutiono. ferrisutionoa@yahoo.com

\section{INTRODUCTION}

The main causes of infant morbidity and mortality are obstetrics and perinatology problem. It is close to preterm birth. $70 \%$ of neonatal morbidity and mortality are caused by prematurity. More than $65 \%$ of neonatal deaths occur in infants born preterm, with a mortality rate of 19,000 per year. ${ }^{1,2}$ American College of Obstetrician and Gynecologist (ACOG) stated that the definition of preterm labor is labor that occurs before 37 weeks gestation or less than 259 days from the first day of the last menstrual period (LMP). Meanwhile, according to the World Health Organization (WHO), preterm birth is defined as birth that occurs before 37 weeks gestation, with intact fetal membrane. ${ }^{3}$ In outline, preterm labor are classified into three major groups, there are: $25 \%$ of preterm labor occurs with indication of unstable condition of mother or fetal status. Preterm rupture of membranes cause $30 \%$ of preterm labor, whereas preterm labor that occurs spontaneously without prior rupture of membranes $40-50 \%$, with half the cause is ascending infection on genital tract that causes intrauterine infection. ${ }^{2,4}$

Some literature states that infection and inflammation lead to more than $50 \%$ of preterm pregnancies. ${ }^{5}$ Significant increase of inflammatory mediators will trigger a substance released as regulator of inflammatory response. Protease inhibitors act as inflammatory response regulator as well as inhibitors to the elastase products. ${ }^{6}$ Secretory leukocyte protease inhibitor (SLPI) is the most potent protease inhibitor in inhibiting the 
inflammatory process against Neutrophil Elastase (NE) that can cause the cervix to soften. Secretory leukocyte protease inhibitor excreted during pregnancy with the highest concentration found on the cervical mucus and serves as the main barrier to infection in the genital tract during pregnancy. SLPI secreted dominantly by the decidua, especially the parietal decidua and korio decidua. Lower levels secreted by the amnion and placenta. ${ }^{7,8}$ Increasing concentrations of SLPI would form inflammatory interactions in maintaining a pregnancy and then limit it during delivery. Anti-microbiological effects caused by SLPI would protect the uterus during implantation and prevent infection during pregnancy. $3,5,7$ Based on the function of SLPI above, research conducted with the aim to determine the concentration differences of SLPI in preterm labor and preterm pregnancy with intact membranes, and determine SLPI cutoff point to predict the preterm labor incidence.

\section{METHOD}

In this research, the design used was crosssectional by comparing concentrations of Secretory Leukocyte Protease Inhibitor (SLPI) on research subjects serum, among preterm labor without preterm rupture of membranes and preterm pregnancy. This research conducted in Section / SMF Obstetrics and Gynecology Faculty of Medicine, Universitas Sam Ratulangi, Prof. Dr. R.D. Kandou Central General Hospital Manado and network hospitals Department of Obstetrics and Gynecology Faculty of Medicine Universitas Sam Ratulangi, began in September 2016 until the samples quantity fulfilled. The samples were pregnant women who experience preterm labor in the delivery room of RSUP Prof. Dr. R. D. Kandou Manado and network hospital that met the inclusion criteria. The control group was 20-36 weeks pregnant women who checkups in Obstetric Polyclinic RSUP Prof Dr. R.D. Kandou Manado and network hospital. Sample collected by consecutive sampling where every subject which met the research criteria included in the research up to a certain time until the number of samples fulfilled. The inclusion criteria were $20-36$ weeks pregnant women based on the first day of the last menstrual period, active phase labor stage 1 , live singleton pregnancies lies the head, intact membranes, no complications or obstetric complications, and patients willing to participate in research and signed an informed consent sheet. While exclusion criteria were pregnant women with preterm labor history in previous pregnancy, has systemic infection on the subject, there are congenital malformations in the fetus, and refused to follow the research.

The number of samples using single mean formula with reference to the SLPI concentration in women with intact membranes preterm labor i.e. $698 \mu \mathrm{g} / \mathrm{l}$ (ranges: 320-1054 $\mu \mathrm{g} / \mathrm{l}$; standard deviations assumption $250 \mu \mathrm{g} / \mathrm{l}$ ).

$$
\begin{aligned}
& \mathrm{n}=\left(\frac{\mathrm{Z}_{\alpha}{ }^{2} \sigma}{\mathrm{d}^{2}}\right)=15.4=16 \\
& \mathrm{n}=\text { number of samples }=15.4=16 \\
& \mathrm{Z}_{\alpha}=1.96 \\
& \sigma=\text { standard deviation }=250 \mu \mathrm{g} / \mathrm{l} \\
& \mathrm{d}=\text { desired accuracy }=125 \mu \mathrm{g} / \mathrm{l}
\end{aligned}
$$

So number of samples $=32$ (each of the 16 women with intact membranes preterm labor 16 women with intact membranes term labor). The statistical test is t-test (independent samples; 2 mean difference), or equivalent non-parametric tests, i.e. the Mann-Whitney test. The cut-off point, sensitivity, and specificity will be determined using analysis of Receiver Operating Curve (ROC).

\section{RESULT}

A total 32 subjects consisting of 16 pregnant women who experienced preterm labor and 16 pregnant women with preterm pregnancy were recruited. Characteristics of the subjects are presented in Table 1.

Table 1. Characteristics Subject on Both Group Research

\begin{tabular}{lcccc}
\hline \hline \multirow{2}{*}{ Characteristic } & \multicolumn{2}{c}{ Preterm Labor } & \multicolumn{2}{c}{ Preterm Pregnancy } \\
& $\mathbf{n}$ & $\mathbf{\%}$ & $\mathbf{n}$ & $\mathbf{\%}$ \\
\hline Age & & & & \\
$\quad \leq 24$ & 7 & 43.75 & 5 & 31.25 \\
$25-34$ & 7 & 43.75 & 5 & 31.25 \\
$>34$ & 2 & 12.5 & 6 & 37.5 \\
Parity & & & & \\
0 & 3 & 18.75 & 5 & 31.25 \\
1 & 5 & 31.25 & 4 & 25
\end{tabular}




\begin{tabular}{lcccc}
2 & 5 & 31.25 & 4 & 25 \\
3 & 1 & 6.25 & 1 & 6.25 \\
4 & 2 & 12.5 & 2 & 12.5 \\
Mass Body Index & & & & \\
$\quad<19.8$ & 2 & 12.5 & - & 0 \\
$19.9-26$ & 8 & 50 & 7 & 43.75 \\
$26.01-29.99$ & 5 & 31.25 & 6 & 37.5 \\
$>30$ & 1 & 6.25 & 3 & 18.75 \\
\hline Antenatal Care & & & & \\
$\quad<$ three times & 7 & 43.75 & 6 & 37.5 \\
$\quad \geq$ four times & 9 & 56.25 & 10 & 62.5 \\
Left Upper Arm & & & & \\
Circumference & & & & \\
$\quad \leq 23.5$ & 2 & 12.5 & 2 & 12.5 \\
$\quad>23.5$ & 14 & 87.5 & 14 & 87.5 \\
\hline \hline
\end{tabular}

From the above data obtained maternal age in the group of preterm labor $<24$ years as many as seven people (43.75\%) and ages 25-34 years as many as seven people (43.75\%). Whereas in the group of preterm pregnancy obtained age group $<24$ years as many as five people (31.25\%), and ages 25-34 years as many as five people (31.25\%). The highest Parity in the group preterm labor is parity 1 and 2 i.e. 5 people for each with a percentage $31.25 \%$. While groups of preterm pregnancy who present in the obstetric polyclinic the majority were parity 0 as many as five people (31.25\%). The body mass index in the group of preterm labor divided into four groups. The highest number was found in the body mass index between 19.9 to 26 as many as eight peoples (50\%). Whereas in the group of preterm pregnancy that went to the obstetric polyclinic have highest body mass index from 19.9 to 26 as many as seven people (43.75\%). Antenatal care visit in preterm labor group the most are $\geq$ four times as many as nine people $(56.25 \%)$. Whereas in preterm pregnancy group most patients have antenatal care regularly, i.e., ten people $(62.5 \%)$ do antenatal care $\geq$ four times. Left upper arm circumference measurements in preterm labor group most obtained $>23.5 \mathrm{~cm}$ as many as 14 people (87.5\%). Whereas in the group of preterm pregnancy who present at the polyclinic obtained measurements of left upper arm circumference $>23.5 \mathrm{~cm}$ as many as 14 people $(87.5 \%)$.

Table 2. Descriptive SLPI Distribution Level Data

\begin{tabular}{lcc}
\hline \hline Group & Preterm Labor & Preterm Pregnancy \\
\hline Mean & 45.975 & 30.319
\end{tabular}

\begin{tabular}{lcc} 
Median & 41.600 & 29.950 \\
Interval for mean & $41.198-50.752$ & $27.794-32.844$ \\
Standard Deviation & 8.9641 & 4.7389 \\
Range & 25.3 & 16.5 \\
\hline \hline
\end{tabular}

Table 3. SLPI Variable Normality Test (Shapiro Wilk Test)

\begin{tabular}{lc}
\hline \hline Group & p-value \\
\hline Preterm Labor & 0.005 \\
Preterm Pregnancy & 0.652 \\
\hline \hline
\end{tabular}

From Table 2 obtained SLPI concentration ratio between preterm labor and preterm pregnancy. In preterm labor group, obtained mean value for SLPI concentration is 30.319 with standard deviation 4.7389, median 29.950, range 16.5 and the ranges obtained 27.794 - 32.844. In preterm pregnancy group obtained mean value for SLPI concentration 45.975 standard deviations 8.9641, median 41.600, range 25.3 and the range obtained between 41.198 -50.752 .

From the data Shapiro-Wilk normality test seen levels of secretory leukocyte protease inhibitor (SLPI) in preterm pregnancy group is not normally distributed (one of them $\mathrm{p}<0.05$ ), so Mann-Whitney test will be conducted as non-parametric test.

Mann-Whitney non-parametric test showed that $p=0.000$ which means that there are significant differences between SLPI level of preterm pregnancy and preterm labor. Conclusion SLPI levels and preterm labor correlate.

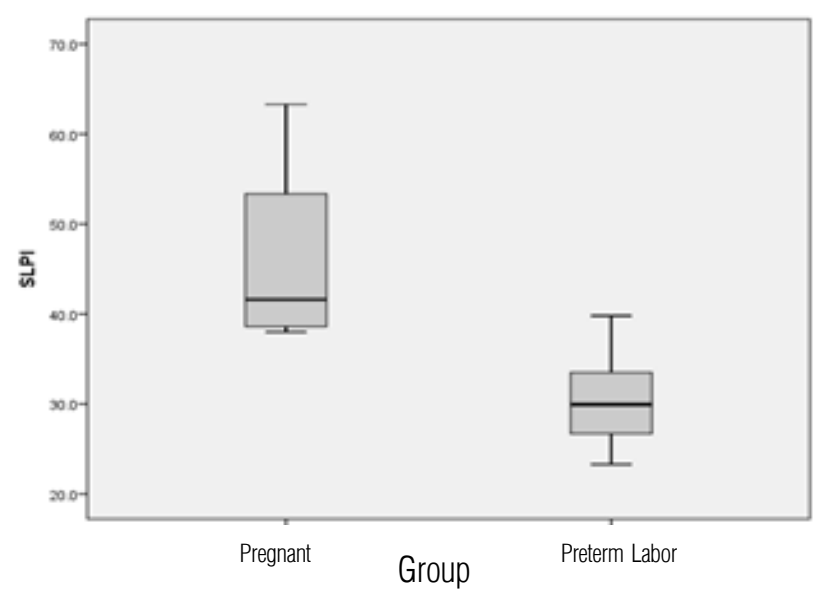

Figure 1. Graphs the Level of SLPI in Preterm Labor and Preterm Pregnancy 


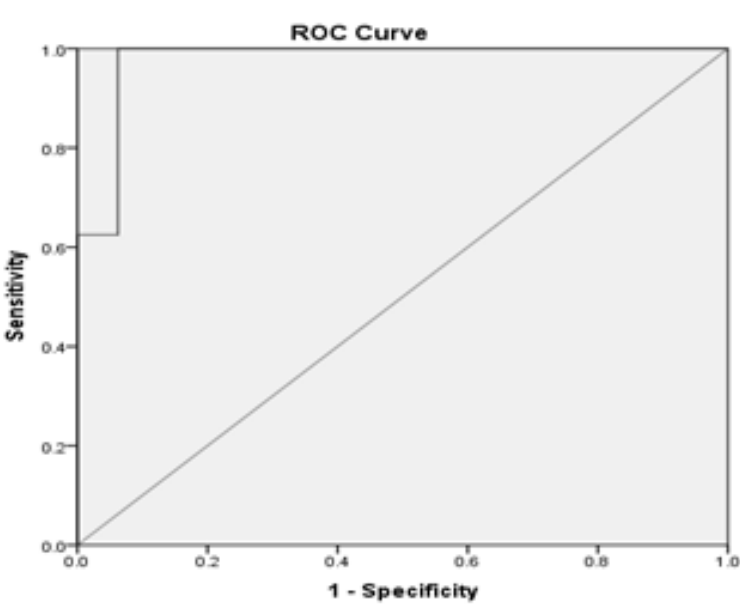

Figure 2. ROC (receiver operating characteristic) Cut off Point of SLPI.

From those data ROC (Receiver Operating Characteristic) curve made to determine the cut-off point of SLPI concentration, i.e., $37.9 \mathrm{ng} / \mathrm{ml}$ with sensitivity $100 \%$ and specificity $93.7 \%$.

\section{DISCUSSION}

Some research says that many demographic factors that imply the risk of preterm labor threat. In term of epidemiology, there are several risk factors for preterm labor, which are ${ }^{9-11}$ :

Idiopathic, Iatrogenic, such as aggravate circumstances to mother or fetus, Infections, both extra and intrauterine, multiple pregnancies, maternal factors: stress in mothers, cervical incompetence, disease in mothers, reproductive history: previous prematurity history, ruptured membranes history, abortion history, primipara, too close spaced pregnancies, low maternal weight gain during pregnancy, parity, sociodemographic: low socioeconomic, too young or too old age, race, marital status, unfavorable environmental factors, too heavy daily activities.

A prematurity history in the elderly will be a potentially important factor for the prematurity back in the offspring. Another meta-analysis also noted that prematurity history or intrauterine infection would cause carrier to cytokine inflammatory mediators, and its correlation with genotypic researched continuously. ${ }^{4,12}$

In this research, from the characteristic table showed that the incidence of preterm labor was highest at age less than 24 years and the age of 25-34 years. Too young or too old maternal age also a risk factor for preterm labor. Research in Sweden mentioned that the maternal age during pregnancy between 13-17 years of age increases the risk of preterm labor twice control age of 20-24 years. While on maternal age over 35 years increases the risk of preterm labor twice compared with control age of 20-30 years. ${ }^{5}$ According to creasy, maternal age relationship to preterm labor is the younger the maternal age, the greater the risk preterm labor. Maternal age less than 20 years and maternal age over 40 years has a risk for preterm labor. Maternal age less than 18 years old have greater risk score than 20 years. The preterm labor incidence is much found at younger age due to such factors: socioeconomic, education, and lifestyle habits. ${ }^{9,13}$

Based on some research, preterm labor is more common in primipara. And some research also indicates the preterm labor risk increased in pregnancies of more than four.6,7 In this research obtained highest preterm labor occurred in women with parity 1 and $2 .{ }^{14}$ In the table of research subject characteristics, based on the body mass index obtained the highest number of preterm labor occurrences is 19.9 to 26 for eight patients. Cohen et al. mentioned significant relationship between low maternal body weight or low BMI during pregnancy with preterm labor incidence. Low maternal body weight or low BMI during pregnancy as well as poor nutrition also risk factor for preterm labor. ${ }^{15,16}$ Some anthropometric examination can be used to determine the nutritional status of pregnant mother, one of which is by measuring Left Upper Arm Circumference (LUAC). Through this examination can predict mother experiencing Chronic Energy Deficiency (CED) if LUAC $<23.5 \mathrm{~cm}$. Lack of energy has the risk to deliver a baby with low birth weight and increase the risk to preterm labor. ${ }^{12,17}$ From the MUAC measurement characteristic table in this research, in preterm labor group obtained only two people with LILA measurement $<23.5 \mathrm{~cm}$.

\section{SLPI Concentration in Preterm Labor and Preterm Pregnancy}

SLPI serves as a potent inhibitor and immunity in an inflammatory process, by reducing the inflammatory genes expression and reduce cells inflammatory accumulation, as well as contributing to the immunity balance. In broad outline, SLPI has anti-inflammatory activity, anti-virus, and anti- 
bacterial. ${ }^{18,19}$ SLPI concentration increased from the second trimester to the third trimester, although the concentration changes and activities at the labor onset has not been widely researched. ${ }^{20-22}$ Denison et al. mentioned that SLPI in the amniotic fluid concentration continued to increase since the second trimester until term pregnancy, and at the labor onset. In the second trimester obtained SLPI concentration $24 \pm$ three $\mathrm{ng} / \mathrm{ml}$, whereas the term pregnancy SLPI concentration is $751 \pm 53 \mathrm{ng} / \mathrm{ml}$. The highest concentration of SLPI obtained in term labor onset i.e. 3929 $\pm 107 \mathrm{ng} / \mathrm{ml}^{20}$

Zhang et al., In their research mentioned that SLPI concentration in the amniotic fluid third trimester of pregnancy $(802 \pm 138 \mathrm{ng} / \mathrm{ml})$ higher than SLPI concentration in the second trimester of pregnancy $(106 \pm 15 \mathrm{ng} / \mathrm{ml})$ with the significance value $\mathrm{p}<0.0001$. Helmig et al., mentioned that in preterm pregnancy with preceded rupture membrane, has an SLPI concentration average value in amniotic fluid lower that intact membrane, i.e., 579 $\mu \mathrm{g} / \mathrm{l}$ in rupture membrane pregnancy and 1038 $\mu \mathrm{g} / \mathrm{l}$ in intact membrane pregnancy. ${ }^{23}$ From some of conducted research, it can be concluded that the increased SLPI with age pregnancy serves to maintain the pregnancy of inflammatory process that can cause preterm labor. Several studies of the low concentration of SLPI in the amniotic fluid in preterm rupture case due to lower anti-protease activity, where in the protease has the ability in membrane degradation that can soften and ripen the cervix. SLPI concentration reduction will result in decreased in SLPI antimicrobial effect to the uterus, that can cause infection and lead to preterm labor. ${ }^{24,25}$

This is consistent with research conducted by Punchner et al. where SLPI concentration assessed in spontaneous preterm labor with prior rupture preterm labor. From these studies obtained low concentrations of SLPI in prior rupture preterm labor case. Theoretically can be explained that the low concentration of SLPI in rupture of membranes associated with the inflammatory process. In this research, research conducted on 16 patients with preterm pregnant mother compared with 16 patients mothers who experience preterm labor without ruptured membranes. Blood sampling performed on all samples and tested in the laboratory. Then conduct Mann - Whitney non-parametric test which showed that $p=0.000$ which means obtained statistically significant difference of SLPI concentration values between groups of preterm labor and preterm pregnancy. So the results of this research can prove that low levels of SLPI is one of the preterm labor causes.

\section{SLPI Cut Off Point}

Some research that done previously stated, there is a tendency to lower concentration of SLPI in preterm labor case, by using amniotic fluid as SLPI concentration inspection material. However, some researchers got different SLPI concentration values and still have not found SLPI concentration cut off point to be used as a predictor of preterm labor without prior rupture. In this research, based on ROC curve obtained SLPI concentration cut off points mark of the preterm labor incidence is 37.9 $\mathrm{ng} / \mathrm{ml}$. If the SLPI concentration value $\leq 37.9$ in women with a gestational age $<37$ weeks may lead to preterm labor with sensitivity $100 \%$ and specificity $93.7 \%$. Expected the SLPI concentration assessment result in this research can serve as guidelines to predict preterm labor risk during antenatal as early detection.

\section{REFERENCES}

1. Cunningham FG, Leveno KJ, Bloom SL, Spong CY, Dashe JS, Hoffman BL, et al. Williams Obstetrics. 24th ed. New York: McGraw-Hill Education; 2014: 804-37.

2. Romero R, Chaiworapongsa T. Preterm labor, intrauterine infection, and the fetal inflammatory response syndrome. Neo Reviews. 2002; 3(5): e73-e85.

3. Abadi A. Persalinan Preterm. Dalam: Hariadi R, editor. Ilmu Kedokteran Fetomaternal. Surabaya: Himpunan Kedokteran Fetomaternal Perkumpulan Obstetri and Ginekologi Indonesia; 2004: 364-79.

4. Lemancewicz A, Laudanski P, Kuc P, Pierzynski P, Kretowska M, and Urban J. Matrix metalloproteinase-2 and tissue inhibitor of metaloproteinase- 2 urine levels in preterm labouring patients. Arc Perinatal Med. 2007; 13(2): 50-2.

5. Goldenberg RL, and Rouse DJ. Prevention of premature birth. Med Prog. 1998; 339(5): 313-20.

6. Doumas S, Kolokotronis A, and Stefanopoulos P. Anti-Inflammatory and Antimicrobial Roles of Secretory Leukocyte Protease Inhibitor. Infect Immunity. 2005; 73(3): 1271-4.

7. Singh U, Nicholson G, Urban BC, Sargent IL, Kishore U, and Bernal AL. Immunological properties of human decidual macrophages - a possible role in intrauterine immunity. Reprod. 2005; 129: 631-7.

8. Dalgetty DM, Sallenave JM, Critchley HOD, Williams AR, Tham WY, King AE, et al. Altered secretory leukocyte protease inhibitor expression in the uterine decidua of tubal compared with intrauterine pregnancy. Hum Reprod. 2008; 23(7): 1485-90. 
9. Goldenberg RL, Culhane JF, Iams JD, and Romero R. Epidemiology and causes of preterm birth. The Lancet. 2008; 371(9606): 75-84.

10. Goldenberg RL, Hauth JC, and Andrews WW. Intrauterin Infection and Preterm Delivery. N Engl J Med. 2000; 342: 1500-7.

11. Malamitsi-Puchner A, Vrachnis N, Samoli E, Baka S, Iliodromiti Z, Puchner K-P, et al. Possible Early Prediction of Preterm Birth by Determination of Novel Proinflammatory Factors in Midtrimester Amniotic Fluid. Ann NY Acad Sci. 2006; 1092: 440-9.

12. Chan RL. Biochemical markers, of spontaneous preterm birth in asymptomatic women. Bio Med Research Int. 2014; 1-8.

13. Tucker J, and McGuire W. ABC of preterm birth. Epidemiology of preterm birth. BMJ. 2006; 329: 675-8.

14. Sutarjo US, and Primadi O. Profil Kesehatan Indonesia 2014. Jakarta: Kementerian Kesehatan Republik Indonesia; 2015: 108.

15. Goldenberg RL, Hauth JC, and Andrews WW. Intrauterine Infection and Preterm Delivery. N Eng J Med. 2000; 342: 1500-7.

16. Holst D., Garnier Y. Preterm birth and inflammation - The role of genetics polymorphisms. Eur J Obstet Gynecol Reprod Biol, 2008; 141: 3-9.

17. Klein LL, and Gibbs RS. Infection and preterm birth. Obstet Gynecol Clin North Am. 2005; 32: 397-410.

18. Velarde MC, Parisek SI, Eason RR, Simmen FA, and Simmen RCM. The secretory leukocyte protease inhibitor gene is a target of epidermal growth factor receptor action in endometrial epithelial cells. J Endocrinol. 2005; 184: 141-51.
19. Tjabringa GS, Vos JB, Olthuis D, NinaberDK, Rabe KF, Schalkwijk J, et al. Host defense effector molecules in mucosal secretions. FEMS Immunol Med Microbiol. 2005; 45: 151-8.

20. Helmig BR, Romero R, Espinoza J, Chaiworapongsa T, Bujold E, Gomez R, et al. Neutrophil elastase and secretory leukocyte protease inhibitor in prelabor rupture of membranes, parturition, and intra-amniotic infection. J Maternal-Fetal Neonatal Med. 2002; 12: 237-46.

21. Velarde MC, Parisek SI, Eason RR, Simmen FA, and Simmen $\mathrm{RCM}$. The secretory leukocyte protease inhibitor gene is a target of epidermal growth factor receptor action in endometrial epithelial cells. J Endocrinol. 2005; 184: 141-51.

22. PuchnerAM, VrachnisN, Samoli E, Baka S, et al. Possible early prediction of preterm birth by determination of novel proinflammatory factors in mid-trimester amniotic fluid. Ann. N.Y. Acad Sci, 2006; 1092: 440-9.

23. Ota Y, Shimoya K, Zhang Q, Moriyama A, Chin R, Tenma K, et al. The expression of secretory leukocyte protease inhibitor (SLPI) in the Fallopian tube: SLPI protects the acrosome reaction of sperm from inhibitory effects of elastase. Hum Reprod. 2002; 17(10): 2517-22.

24. King AE, Critchley HOD, and Kelly RW. Innate immune defenses in the human endometrium. Reprod Biol Endocrinol. 2003; 1(116): 1-8.

25. Zhang Q, Shimoya K, Moriyama A, Yamanaka K, Nakajima A, Nobunaga t, et al. Production of secretory leukocyte protease inhibitor by human amniotic membranes and regulation of its concentration in amniotic fluid. Mol Hum Reprod. 2001; 7(6): 573-9. 